by Inna Safonova ${ }^{1,2 *}$, Shigenori Maruyama ${ }^{1,3}$, Nikolai Kruk ${ }^{1,4}$, Olga Obut $^{1,4}$, Pavel Kotler ${ }^{1,2}$, Olga Gavryushkina ${ }^{1,2}$, Sergey Khromykh ${ }^{1,2}$, Maxim Kuibida ${ }^{1,2}$, and Sergey Krivonogov ${ }^{1,2}$

\title{
Pacific-type orogenic belts: linking evolution of oceans, active margins and intra-plate magmatism
}

\author{
${ }^{1}$ Novosibirsk State University, Pirogova St. 2, Novosibirsk, 630090, Russia; *Corresponding author, E-mail: inna03-64@mail.ru \\ ${ }^{2}$ Sobolev Institute of Geology and Mineralogy SB RAS, Koptyuga ave. 3, Novosibirsk, 630090, Russia \\ ${ }^{3}$ Earth-Life Science Institute, Tokyo Institute of Technology, E-16, 2-12-1, Ookayama, Meguro, Tokyo 152-8550, Japan \\ ${ }^{4}$ Trofimuk Institute of Petroleum Geology and Geophysics SB RAS, Koptyuga ave. 3, Novosibirsk, 630090, Russia
}

(Received: November 20, 2016; Revised accepted: January 15, 2018)

http://dx.doi.org/10.18814/epiiugs/2018/018008

Pacific-type orogens (fold belts) hosting accretionary complexes are places keeping records of the evolution of paleo-oceans, and formation and transformation of continental crust at their active convergent margins. Pacific-type orogeny induces destruction of crustal materials, their subduction to the deep mantle, generation of hydrouscarbonated plumes in the mantle transition zone (MTZ) and its related intra-plate magmatism. We propose a new approach for linking paleo-oceans, active margins and intra-plate magmatism in central and eastern Asia. The approach "stands" on three "whales": the model of Ocean Plate Stratigraphy (OPS), the parameters of Pacific-type convergent margins and a model of hydrous-carbonated plumes. The OPS model evolved from extensive studies of accretionary complexes in the western Pacific, in particular, in Japan; it allows differentiating oceanic plates of one paleoocean and evaluating their sizes and ages. An important issue for reconstructing the history of paleo-oceans is to estimate major parameters of the Pacific-type convergent margins: accreting vs. eroding, geometrical length, and life time. For the eroding margins we must define major periods of tectonic erosion and transportation of oceanic and continental materials to the deep mantle and evaluate a possibility of their accumulation in the MTZ. All this would allow us to develop a holistic model linking the evolution of paleooceans, the accretion and erosion of oceanic and continental crust materials at Pacific-type convergent margins, mantle metasomatism and intra-plate magmatism.

\section{Introduction}

In recent decades, there has been done a big progress in experimental and numerical modeling of global material circulation and deep geodynamics. Unfortunately, many of those models appeared sepa- rated from real geology and therefore cannot be considered trustworthy. We propose a new conceptual model based on both real and "model" geologies. We suggest that indicative minerals, rocks and rock complexes, such as garnet and other minerals of deep-seated xenoliths, alkaline basalt, carbonatite, etc. which are present on the Earth's surface and accessible for our study, are not the only source of information about deep mantle processes. The absence of certain rocks or complexes can also reflect past geological processes on the surface and their effect on the deep interior of our planet.

The popular model of mantle plumes and superplumes implies their generation at the core-mantle boundary (CMB), i.e., at a depth of $2900 \mathrm{~km}$; those plumes are also often termed "dry" plumes (Maruyama, 1994; Maruyama et al., 2007). The superplumes result in voluminous, but typically, rather rapid basaltic eruptions (Reichow et al., 2009) and in the formation of large igneous provinces, for example, Siberian traps or Ontong-Java. According to different evaluations, superplume cycles can be from several tens to hundred million years (Maruyama et al., 2007; Li and Zhong, 2009; Nance and Murphy, 2013). Therefore, the model of "dry" plumes cannot explain the numerous and almost ceaseless manifestations of intra-plate continental magmatism in central and eastern Asia since the amalgamation of the Laurasia supercontinent at $\mathrm{ca}$. $300 \mathrm{Ma}$ and up to the present time (Kuzmin et al., 2010; Safonova and Maruyama, 2014; Yarmolyuk et al., 2014). Recently, an alternative/complementary hypothesis of hydrous-carbonated plumes generated in the MTZ, i.e., at 410-660 $\mathrm{km}$, has been proposed in relation to the processes of subduction and accretion at Pacific-type convergent margins (Kawai et al., 2013; Safonova et al., 2015). During Pacific-type orogeny, new continental crust forms at magmatic arcs and the rocks of oceanic crust are incorporated into accretionary complexes; consequently, both continental and oceanic crust materials can be destructed and subducted to the deep mantle. In a wide sense this problem is a part of the problem of global material circulation from the mantle to the crust at divergent margins and from the crust back to the mantle at convergent margins. However, to turn that hypothesis into a model more evidence from geology, geochronology and petrology of Pacific-type convergent margins, their formation and evolution, mantle metasomatism and mantle 
plumes, is necessary. In this paper, we concisely propose a new approach for developing a holistic model linking paleo-oceans, active margins and plume magmatism recorded in the Pacific-type orogenic belts of Central and East Asia. Such an approach has logically evolved from the results of our IGCP Project \#592 "Continental construction in Central Asia” (2012-2016; Safonova et al., 2011, 2013, 2016a; Xiao et al., 2013).

\section{Pacific-type Convergent Margins and Subduction Zones: Definitions and Importance}

Pacific-type convergent margins (ocean-continent) and their related orogenic belts exist/form over subduction zones, which are the only ways to deliver surface materials to the deep mantle (Fig. 1). The parameters of paleo-oceans and old subduction zones are typically reconstructed by methods of paleomagnetism and paleontology (e.g., Scotese et al., 1994; Stampfli and Borel, 2002; Metcalfe, 2011), which results remain disputable though. A geology-based model of Ocean Plate Stratigraphy (OPS) was proposed by Japanese scientists (Isozaki et al., 1990; Maruyama et al., 2010) and later developed by other researchers (e.g., Kusky et al., 2013; Safonova and Santosh, 2014; Safonova et al., 2016b). OPS is a regular succession of igneous (MORB, mid-ocean ridge basalt; OIB, oceanic island basalt; gabbro-peridotite) and sedimentary (pelagic chert, hemipelagic siliceous sediments, trench turbidite, seamount carbonate "cap", slope and foothill facies) rocks of the oceanic lithosphere, that were, respectively, erupted and deposited on the sea floor as the underlying oceanic basement traveled from the mid-oceanic ridge to the subduction zone (Fig. 2).
During subduction OPS units get accreted to active margins (Fig. 3a) to be later incorporated into accretionary complexes or subducted to the deep mantle. The OPS model can be used as a basis for the reconstruction of paleo-oceans and processes of accretion and subduction at their active margins, or, for example, it can provide solid evidence about the direction of subduction by studying the geometry of duplex structures (Maruyama et al., 2010; Fig. 3b). In addition, the OPS model allows evaluating the size and age of a paleo-oceanic plate (Safonova et al., 2016a), which was subducted million years ago but its small pieces remained on the surface and are now accessible for observation and study (for more details on the methodology see section 3 below).

\section{Accretionary Complexes and Ocean Plate Stratigraphy}

The fragments of oceanic crust or OPS units are important constituents of Pacific-type orogenic belts (Isozaki et al., 1990; Maruyama et al., 2010; Kusky et al., 2013; Safonova et al., 2016b; Safonova, 2017). The subdivision and mapping of accretionary complexes have been always very problematic due to their extremely complicated structure (Fig. 3). Accretionary complexes consist of OPS units scrapped off the subducting oceanic plate and of the material eroded from adjacent arcs. The OPS rocks are of special importance as they record the full history of the oceanic plate from its "birth" at mid ocean ridges to its "death" at subduction zones. Main OPS types are (1) sedimentary and igneous rocks of the oceanic floor: pelagic chert, MORB, gabbro, peridotite; (2) hemipelagic oceanic slope and shelf sediments: siliceous shale, mudstone, and siltstone, which accumulate closer to a trench by transportation of fine-grained material eroded from accretionary

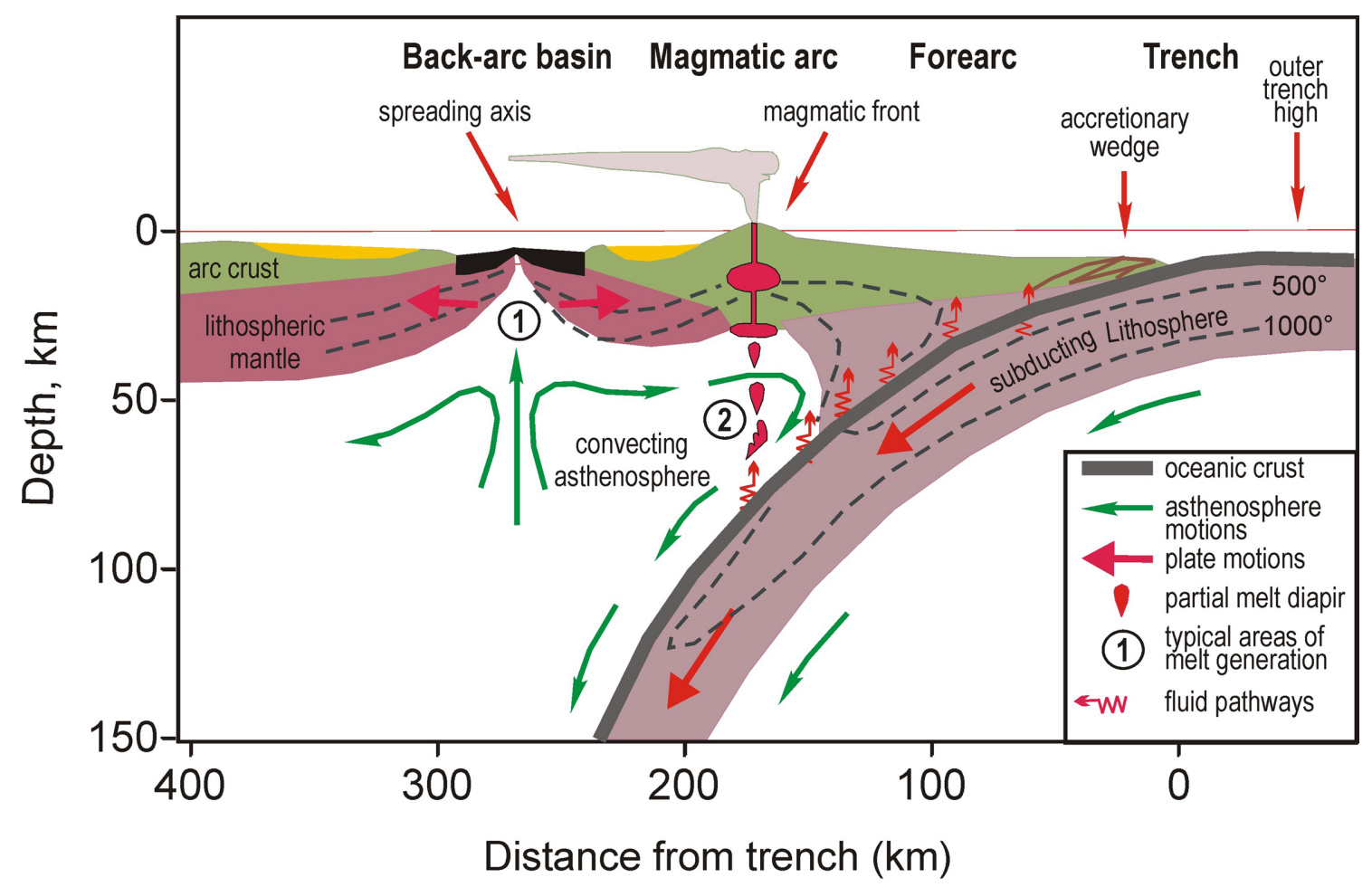

Figure 1. A scheme of a Pacific-type convergent margin showing a typical intra-oceanic arc system with adjacent back-arc basin, major crustal and upper mantle components and major sites of melt generation. (1)-at mid-oceanic ridges, (2)-above the subducting slabs (modified from Stern, 2010). 


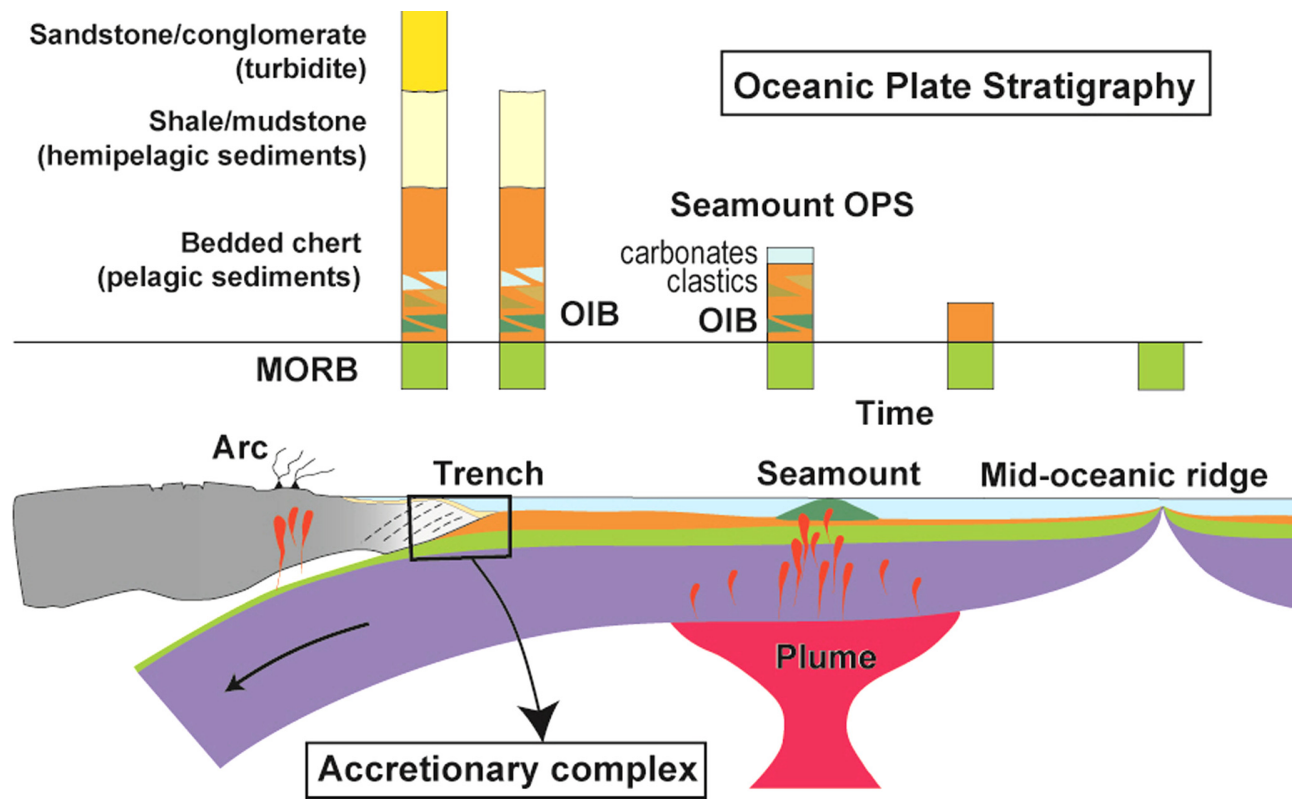

Figure 2. A principal scheme of Ocean Plate Stratigraphy (OPS) with seamounts (modified from Maruyama et al., 2010).

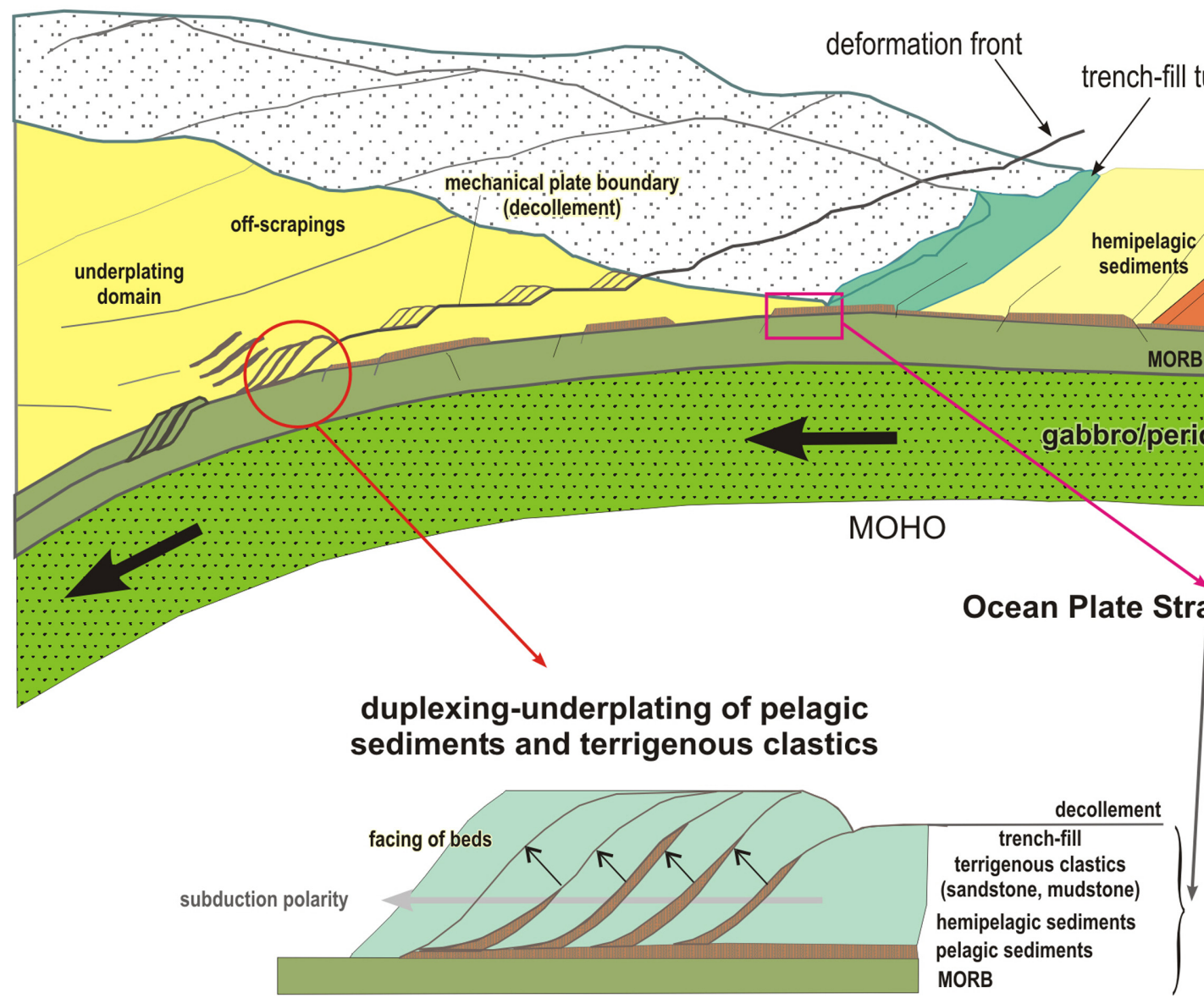

Figure 3. A schematic model for the accretion of deep-sea pelagic sediments and formation of accretionary wedge/complex (a) and for the formation of duplex structures (b) based on the study of the Inuyama area, the OPS type locality, of the Mino terrane in SW Japan (b; Matsuda and lsozaki, 1991). 
wedge and adjacent arcs; (3) trench fill turbiditic sandstone and conglomerate (Kusky et al., 2013; Fig. 2). A special case is seamount OPS (oceanic islands, seamounts, plateaus), which includes OIB-type basalts, which may be capped by shallow-water carbonates (massive/ micritic/reefal limestone), carbonate-volcanogenic epiclastic slope facies and basal siliceous shale and chert (Safonova and Santosh, 2014; Yang et al., 2015). The accreted seamount OPS is of special importance as it can be preserved much more often during subduction, even at eroding active margins, unlike other types of OPS. Although most of the oceanic crust is subducted into the mantle, fragments of OPS may remain on the surface and appear accessible to our study.

\section{Convergent Margins}

Pacific-type convergent margins are places of major continental growth by island-arc juvenile magmatism and accretion (Fig. 1), but they are also places of strong plate interactions and crust destruction. To understand a balance between crust formation and destruction we need to know the type of convergent margin, accreting or eroding (Fig. 4), and its geometry, orthogonal or oblique subduction or transform margin. The periods of continuous subduction, the amount and length of the subduction zones surrounding oceans and continents during certain periods of their evolution, and the types of convergent margins define the amount of the material which could be subducted to the deep mantle. The duration of subduction and therefore the age/size of a subducting oceanic plate can be evaluated by the thickness/age range of OPS sediments (Fig. 2).

Two contrast types of Pacific-type convergent margins have been recognized so far (Scholl and von Huene, 2007). The accreting margins form accretionary complexes and grow oceanward (Fig. 4a). The eroding margins are characterized by the shortening distance between arc and trench, which accompanies the tectonic and subduction erosion of accretionary wedge, fore-arc prism and volcanic arc (Fig. 4b) (Scholl and von Huene, 2007; Stern, 2010; Safonova et al., 2015; Safonova, 2017). The first evidence for the tectonic erosion at Pacific-type convergent margins was obtained from seismic reflection profiles made across the Tonga (Hilde and Fisher, 1979) and Nankai trenches (Hilde, 1983). The modern Pacific is surrounded by $75 \%$ of eroding convergent margins and $25 \%$ of accreting margins (Scholl and von Huene, 2007). The mechanism of tectonic erosion (Fig. 4c) includes destruction of oceanic slab, island arcs, accretionary prism and fore-arc by thrusting, oceanic floor relief (horst/graben), and (hydro)fracturing (von Huene et al., 2004; Yamamoto et al., 2009). Recent studies have shown that the global long-term rate of subduction erosion is much greater than that of crustal additions (Senshu et al., 2009; Stern, 2010). Accordingly, we suggest that the processes of subduction erosion operated back to the Paleozoic and Mesozoic in the paleo-oceans and their related Pacific-type orogenic belts, which closure later formed the the Paleozoic Central Asian Orogenic Belt and those in eastern Asia (Safonova, 2017). Evidence for this comes from the Cretaceous Shimanto accretionary complex in Japan and from the Chatkal-Atbashi arc in the middle Kyrgyz Tienshan. The Shimanto accretionary units are spatially adjacent to the coeval granitoids of the Ryoke belt suggesting that older accretionary complexes have been eroded (Safonova et al., 2015, 2016b). The Chatkal-Atbashi complex includes coeval and spatially adjacent Early Devonian arc granitoids, ophiolites and accretion-
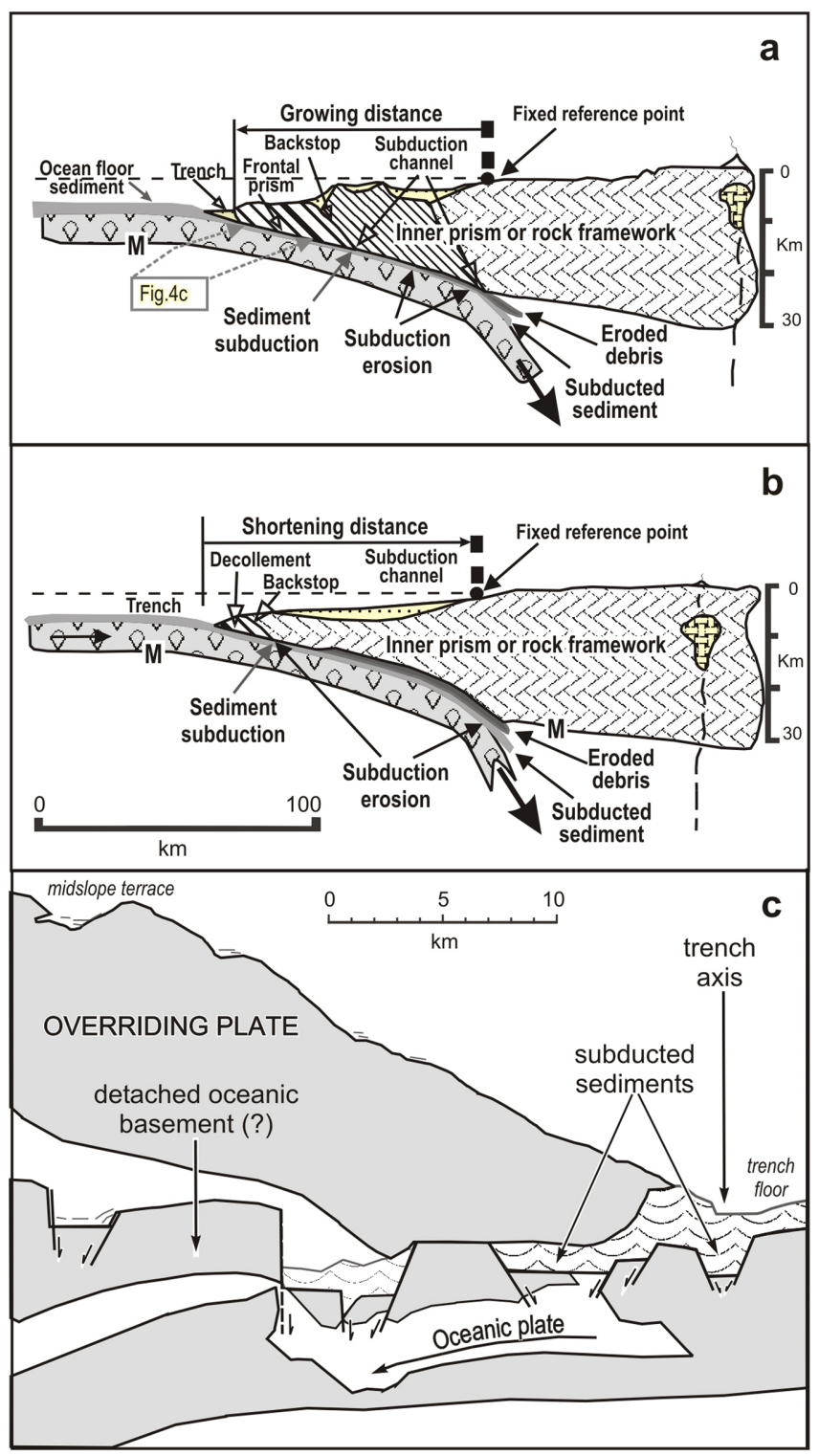

Figure 4. Tectonic erosion at Pacific-type convergent margins. (a and b) Major rock and sedimentary masses of accreting and non-accreting/eroding margins, respectively (modified from Scholl and von Huene, 2007). M-Moho. (c) An interpretation based on a multi-channel seismic reflection profile across the axis and lower slope of the Japan trench along the $35^{\circ} 45^{\prime} \mathrm{N}$ latitude, showing the subducting oceanic slab (modified from Hilde, 1983).

ary units (Alexeiev et al., 2016). At those fossil convergent margins, the continental crust was probably eroded and submerged to the deep mantle.

\section{Materials Subducted to the Mantle}

The major materials, which can be subducted to the deep mantle, are water, carbonates, serpentinite, basalts and sediments of oceanic slab and the rocks of magmatic arcs, both intra-oceanic and continental margin (Yamamoto et al., 2009; Johnston et al., 2011; Kawai et al., 2013; Maruyama et al., 2014; Safonova et al., 2015). The upper part of the subducting oceanic lithosphere consists of water-saturated oce- 


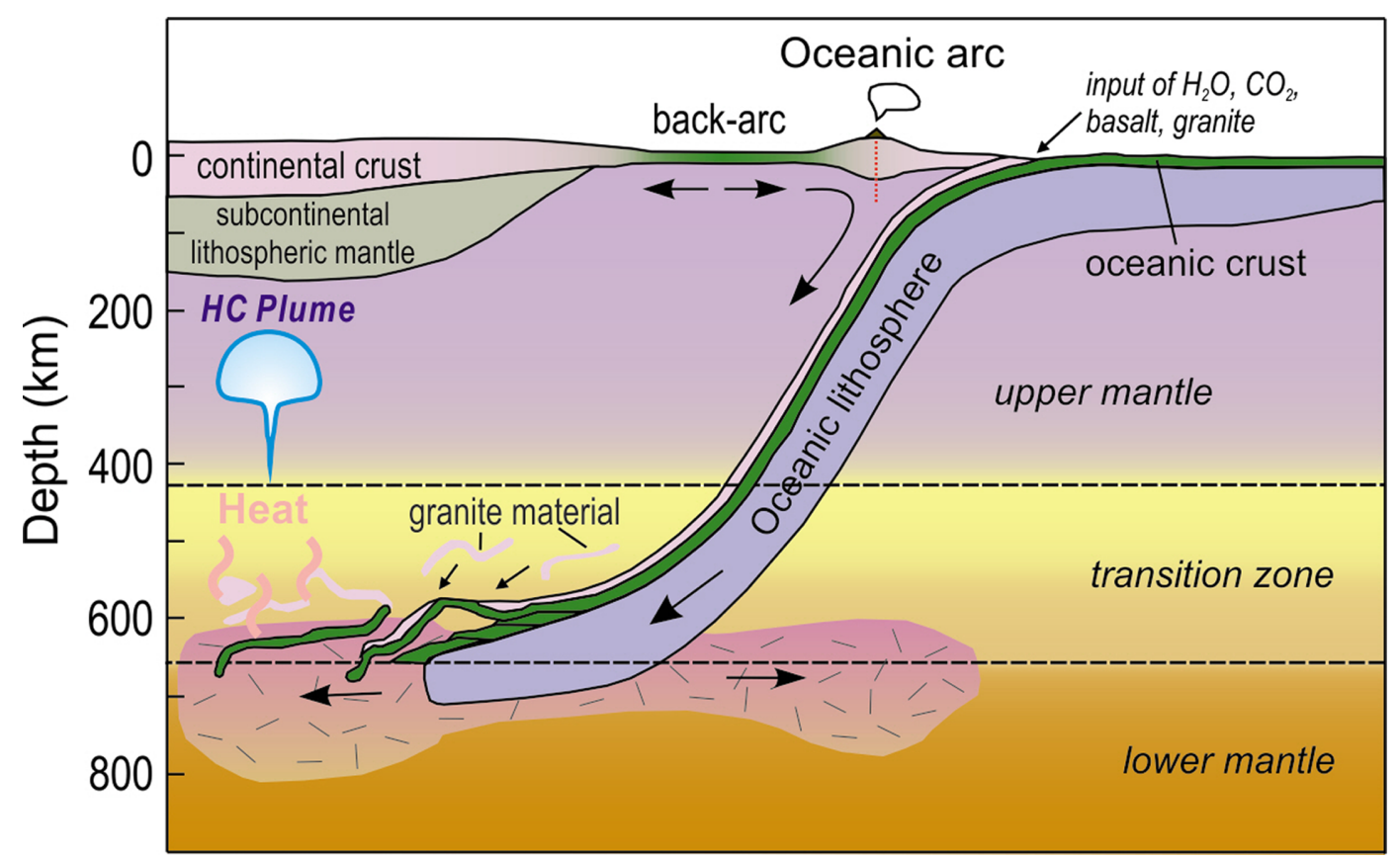

Figure 5. A model of the subduction of different materials to the deep mantle, their accumulation in the MTZ and generation of hydrous-carbonated plumes (modified from Kawai et al., 2013).

anic floor sediments, carbonates and altered (carbonatized, hydrated) basalts and serpentinized peridotite (Fig. 5). The subducting slab can deliver water and carbon dioxide to the mantle and metasomatise it. The OPS model gives us a tool for evaluating parameters of each oceanic plate, first of all, its age and thickness. This is of special importance because the water saturation of subducting plate, the angle of subduction and the rate of slab dehydration - all depend on the thickness, i.e., the age, of the oceanic lithosphere. A maturing oceanic plate gets thicker, i.e., higher saturated in water and carbon dioxide, and heavier, i.e., stronger bent down and stronger faulted. The faults provide direct penetration of water through the crust and the big thickness and subduction angle provide faster subduction and lower slab dehydration (Maruyama et al., 2014; Safonova et al., 2015). In addition, mature oceanic lithosphere typically carry more oceanic rises, which, when approaching the convergent margin, enhance tectonic erosion.

Recently it has been proved that granitic material, containing much higher concentrations of radioactive elements $(\mathrm{K}, \mathrm{Th}, \mathrm{U})$ and consequently representing an addition source of heating in the mantle, but having lower density compared to mafic and ultramafic rocks, also can be subducted. This is possible by a mechanism of viscous dragging acting in the subduction channel and due to the disintegrated (crushed) state of such a material (Kawai et al., 2013; Ichikawa et al., 2015). The physical process of granite subduction is still unclear and requires comprehensive and novel, both numerical and experimental, petrologic studies. However, a recent comparative study of the densities and seismic wave velocities of major mantle lithologies has shown that the accumulation of granitic materials is possible in the MTZ only, but not deeper (Kawai et al., 2013; Ichikawa et al., 2015; Safonova et al., 2015). The data from seismic tomography (Huang and Zhao, 2006) show that the fragments of dehydrated oceanic slabs, which melting temperature is $200 \mathrm{~K}$ lower than that of the ambient mantle, can be also accumulated in the MTZ (Fig. 5). The mantle metasomatism, which is related to the subduction of volatiles, also can decrease the melting temperature of mantle peridotite (Morris et al., 1987; Litasov et al., 2000). Thus, the many kinds of materials, which are eroded at Pacific-type convergent margins, can accumulate in the MTZ and induce mantle metasomatism. All those processes, the subduction of hydrated and carbonated oceanic crust, the destruction of continental crust and accretionary complexes at eroding margins, and the accumulation of mafic and sialic materials in the MTZ, can synergistically trigger the generation of hydrous-carbonated mantle plumes in the MTZ, slab and mantle melting at a depth of approximately $410 \mathrm{~km}$, mantle upwelling, surface rifting and intra-plate magmatism (Maruyama et al., 2009; Yamamoto et al., 2009; Kawai et al., 2013; Safonova et al., 2015) (Fig. 5).

\section{Methodology}

\section{Age and Size of Oceanic Plate}

The parameters of paleo-oceans (age, size) and their surrounding subduction zones (length, life time), the type of convergent margins, accreting or eroding, and the major periods of tectonic and subduction erosion can be reconstructed based on the geological models developed in the modern western Pacific: OPS, subduction/tectonic erosion, big mantle wedge, etc. (e.g., Isozaki et al., 1990; Wakita and Metcalf, 2006; Yamamoto et al., 2009; Maruyama et al., 2010, 2014; Kusky et al., 2013) (Figs. 1-3). This is of special importance for the ancient P-type orogens of central and eastern Asia (e.g., Windley et al., 2007; Safonova et al., 2011), because the young western Pacific accretionary belts are their actualistic analogs.

First, it is necessary to distinguish different oceanic plates within 
one orogenic belt and evaluate their sizes and ages using the OPS model (Fig. 2). In Pacific-type orogenic belts and their related accretionary complexes, the initial geological relationships between igneous and sedimentary rocks are typically strongly disturbed (Fig. 3). Field observations of outcrops show that OPS units occur as small to giant fragments or blocks of olistostromes or tectonic mélanges submerged into shale-sandstone matrix. Therefore, direct reconstruction of primary relationships between rocks is often difficult or even impossible. However, the application of the OPS model coupled with a careful study of OPS units in field and laboratory can help. To do this, OPS pieces should be carefully described and mapped, their lithology, composition and age carefully studied and then interpreted based on the OPS model (basalt-pelagic chert-hemipelagic fine-grained siliceous clastics, shale-trench turbidite; Fig. 2). Repetition of those cycles in accretionary complexes suggests cessation of subduction of one oceanic plate and beginning of subduction of another plate. Ignoring the OPS model may result in fallacious conclusions even if rocks look not disturbed because (1) the classic Steno's law does not work in accretionary complexes; (2) accreted oceanic sediments may be still weakly consolidated, i.e., water-rich and consequently ductile, thus providing "blurred", poorly recognizable linking faults between OPS packages or "horses" (McClay, 1992). During accretion, the "basaltchert-shale" sequences scrapped off the oceanic plate can be piled over each other to form "duplex" structures, in which the older units may appear on the top because the younger units approaching the accretionary complex should rather thrust under thos accreted before (Maruyama et al., 2010) (Fig. 3).

The mechanism of accretion and formation of accretionary complexes is very important to understand, which types of OPS lithologies are involved into accretion at which stage. The geological, lithological and seismic reflection data from SW Japan, from the youngest Nankai accretionary wedge and to the Inuyama area of the Mino terrane hosting Permian OPS (e.g., Isozaki et al., 1990; Kuramoto et al., 2000; Strasser et al., 2009), show that OPS units are incorporated into an accretionary complex through their detachment along the surface of decollement and subsequent exhumation (Figs. 3a and 4a). The depth of decollement depends on the age of the oceanic plate: the older is the plate, the deeper is the decollement (Safonova et al., 2016b). In case of the Nankai trench, the depth of decollement ranges from 0 to ca. $50 \mathrm{~km}$. The age of the OPS detached from the Philippine plate also ranges from zero to several dozens of million years. The lithological package of the detached OPS depends on the younger to older age of the plate and accordingly ranges from: (1) sandstone/shale (trench/hemipelagic) to (2) sandstone/shale and pelagic chert, then (3) sandstone/ shale, chert and MORB,and finally (4) sandstone/shale, chert, MORB and gabbro ( \pm peridotite), plus (5) seamount OPS consisting of OIB, foothill siliceous sediments, carbonate-volcanogenic slope facies and carbonate "cap"). Thus, based on the lithological package and the age range of oceanic sediments we can define OPS type, evaluate the depth of decollement and conclude about the age and size of the oceanic plate.

\section{Evaluation of Parameters of Pacific-type Convergent Margins}

Supra-subduction complexes can be discriminated as intra-oceanic arcs (Mariana type) and continental margin arcs (Andean type) by using geological data, such as the presence or absence of marginal or backarc basins, remnant arcs, fore-arc fans, etc. (Fig. 1) and geochemical, isotope and petrologic data, which may help to define the type of a dominating igneous series: boninitic and/or tholeiitic for MarianaBonin type terranes (e.g., Pearce et al., 1992; Taylor et al., 1994) and calc-alkaline and/or alkaline (shoshonitic) for Andean-type terranes (e.g., Déruelle, 1978; Barrie, 1993). The periods of continuous subduction will be estimated also by using the OPS model, i.e., by the age range for each OPS cycle: from the formation of oldest MORB and chert to the formation of youngest turbidites (Fig. 2). The length and amount of island arcs, proportions of accreting and eroding margins for each period and the volumes of accreted/eroded materials can be evaluated by studying geological maps and topographic maps using GIS technologies (Safonova et al., 2017). The angle and direction of subduction can be determined (i) by the geometry of folding and thrust surfaces separating accreted OPS sheets, (ii) by the direction of formation and migration of duplex-structures (Maruyama et al., 2010; Cleven et al., 2015) (Figs. 3b and 4b) and (iii) by the zonal distribution of island-arc igneous series: from boninitic, to tholeiitic, calcalkaline and shoshonitic (Wilson, 1989).

Of special importance is recognition of major periods of continental crust formation, i.e., formation of TTG-type rocks, andesites and granodiorites, possessing high concentrations of radioactive elements (Maruyama et al., 2014; Safonova et al., 2015). Another issue of identification of P-type orogens is evaluation of proportions of juvenile and recycled crust. This must be based on U-Pb ages, geochemical data, Sm-Nd whole-rock isotopes and Hf-in-zircon isotopes (Safonova, 2017).

Identification of eroding margins needs evaluating the distance between coeval arc and accretionary prism (Safonova, 2017), trench and/or fore-arc wedge (Fig. 4b) using geological and topographic maps, GIS technologies and field observations. A careful study of field relationships between trench deposits, older arc granitoids and coeval fore-arc (accretionary) prism to understand the probability of tectonic erosion of the older units in between is obligatory. The periods of maximal accretion and erosion can be inferred from the periods of continuous subduction and the periods of maximal accretion of OPS from largest oceanic plates and those of minimal accretion to find orogenic belts with signs of tectonic erosion. The amount of granitoid materials, which could be delivered to the deep mantle (see the average rough estimates in Kawai et al., 2013), must be correlated with the type of the granitoids containing increase concentrations of radioactive elements (Th, $\mathrm{U}, \mathrm{K}$ ), which formed in the backyards of magmatic arcs.

\section{P-type Belts of Central Asia}

The main parameters of P-type orogenic belts, which can be evaluated using the approaches presented in Sections 2, 3, are (i) type of margin, accreting or eroding, (ii) type of supra-subduction complex (intra-oceanic or continental margin arc); (iii) length and amount of island arcs; (iv) periods of continuous subduction; (v) type of accreted OPS. Major periods of tectonic erosion of oceanic and continental materials and therefore the volumes of eroded and further subducted materials can be inferred from the life time of eroding margins (Fig. 4b). Also we should distinguish dominant types of materials, which 
can be subducted to the deep mantle (water, carbon dioxide, oceanic crust serpentinite and basalt, continental crust granitoids; see Section 2.3), and to substantiate the accumulation of those materials in the mantle transition zone (MTZ) (Fig. 5).

The accretionary complexes of Central Asia host OPS units/terranes formed during four major age intervals: late Neoproterozoicearly Paleozoic (Russian-Kazakh-Chinese-Mongolian Altai, East and West Sayan, Transbaikalia), Middle Paleozoic-early Carboniferous (Kazakh-Kyrgyz-Uzbek-Tajik Tienshan, East Kazakhstan, Mongolia); late Carboniferous-Permian (Russian Far East: Sikhote-Alin), Triassic-Neogene (Russian Far East: Sikhote-Alin, Sakhalin, and Kamchatka) (e.g., Buslov et al., 2001; Windley et al., 2007; Sun et al., 2008; Safonova et al., 2011, 2016a; Safonova, 2014; Safonova and Santosh, 2014; Yarmolyuk et al., 2014; Simonov et al., 2015; Alexeiev et al., 2016). The structure and age of OPS units of each age group can be used (1) to identify and classify OPS units (pelagic-hemipelagic-trench-seamount); (2) to reconstruct the size and age of each oceanic plate by the depth of decollement (i.e., by recognizing one of 4 types of OPS: ss, css, bcss, gbcss ${ }^{(1)}$ ) (Safonova et al., 2016b), (3) to estimate the number and length of subduction zones, (4) to estimate the rate of sedimentation, (5) to determine the direction of subduction, (6) to highlight the periods of maximal accretion of oceanic crust (for thickest accretionary complexes) and maximal subduction and tectonic erosion.

The most promising areas of tectonic, subduction and other types of erosions in Central Asia are Russian Altai, East Kazakhstan, South Tienshan and Transbaikalia (Safonova, 2017). To prove tectonic erosion we must (1) discriminate intra-oceanic (Mariana-type) and continental (Andean-type) arcs by petrological, geochemical and isotope data; (2) identify related fore-arc prism and trench units; (3) determine the age of igneous and sedimentary rocks; (4) estimate the distance between coeval arc and fore-arc prism or trench.

\section{Mantle Metasomatism and Mantle Plumes}

The longer are the periods of tectonic erosion and subduction, the larger will be the volume of the material arriving to the mantle, metasomatising it and thus reducing melting temperatures. According to rough evaluations based on the average rate of ocean plate subduction and the ages of mantle metasomatism beneath the Siberian platform and the age of kimberlite magmatism therein (Kolesnichenko et al., 2017), the age of metasomatism in the upper mantle can be 50 100 Ma younger than that of the maximal subduction and erosion. For example, the Siberia, Kazakhstan, Tarim and North China continents, which later amalgamated to form supercontinent Laurasia at ca. 300 $250 \mathrm{Ma}$, were surrounded by numerous subduction zones and arcs during the late Paleozoic (Safonova and Maruyama, 2014; Safonova et al., 2015), which could contribute to the initiation of plume magmatism in Mesozoic-Cenozoic time (Kuzmin et al., 2010; Simonov et al., 2015). Since the Miocene, the already amalgamated Eurasian continent has been surrounded by double-sided subduction zones of India-Sumatra and western Pacific, which have been permanently delivering volatiles and other oceanic and continental crust materials to the deep mantle. Consequently, the Quaternary to modern intra-plate volcanism manifested in Transbaikalia, Mongolia and East China (Fig. 6) could be triggered by the oceanic and continental crust mate-

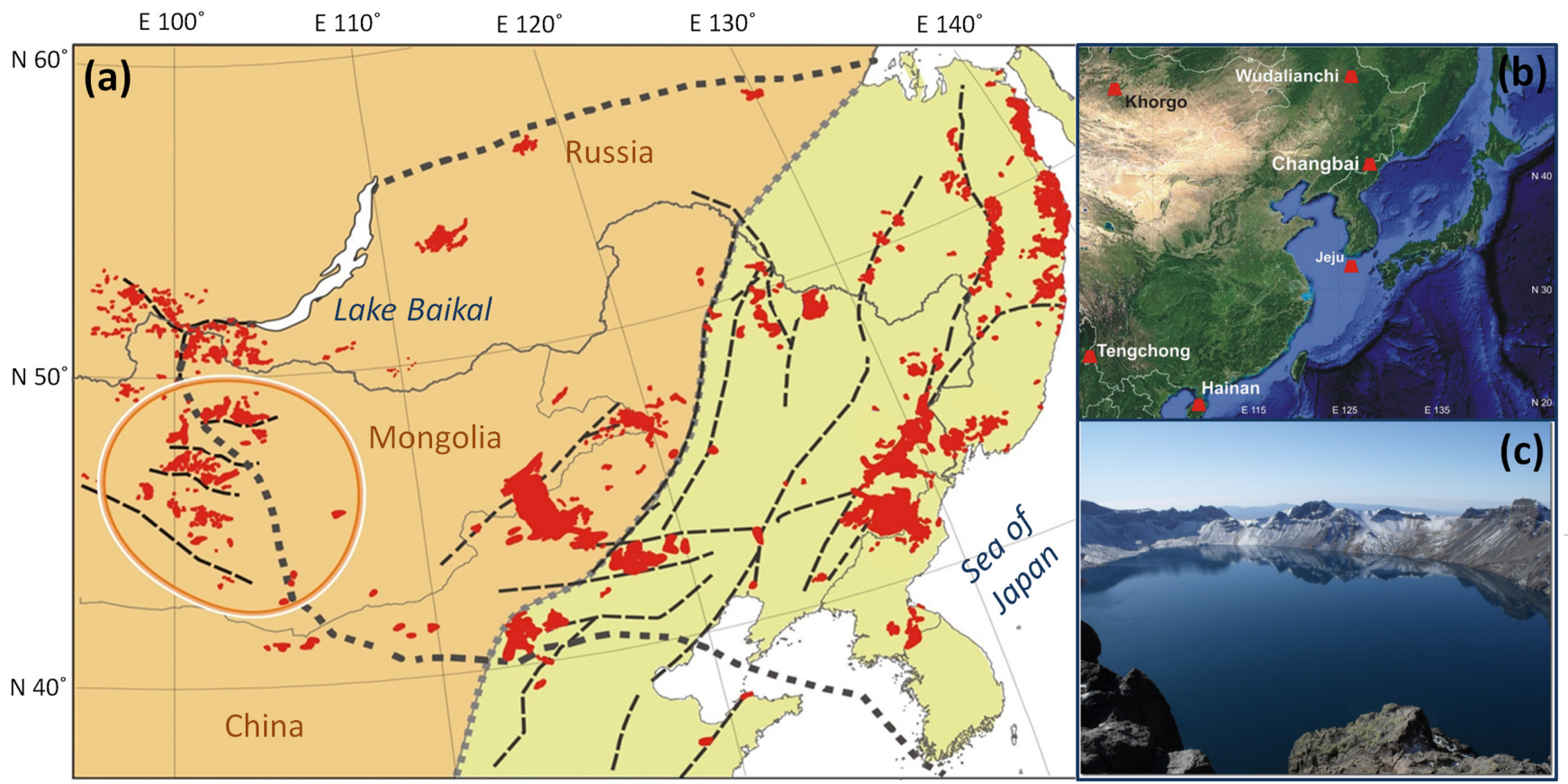

Figure 6. (a) Major Late Cenozoic volcanic provinces in Central and East Asia (modified from Yarmolyuk et al., 2014). (b) Surface topography of the western Pacific to East Asia (modified from Zhao et al., 2011). Red triangles show active intraplate volcanoes. (c) Photograph of Lake Tianchi atop the Changbai volcano (https://bjdeming.com/2014/03/02/changbaishan_baekdu/).

${ }^{(1)}$ Shallow to deep surface of detachment: ss, sandstone/shale; css, chert and sandstone/shale; bcss, MORB, chert and sandstone/shale; gbcss, gabbro ( \pm peridotite), MORB, chert and sandstone/shale (Safonova et al., 2016). 
rials including volatiles supplied by those two giant subduction zones (Maruyama et al., 2007; Safonova et al., 2015). To explore a possibility of the generation of hydrous-carbonated plumes in the MTZ as a result of synergetic interaction of subduction and continental and oceanic crust materials accumulated therein we must correlate the periods of mantle metasomatism, eroding convergent margins and continuous subduction with the periods of intra-plate magmatism and rifting in central and eastern Asia from the late Paleozoic to the Cenozoic.

The presence of volatiles coming from the hydrated and carbonated subducting oceanic crust and the presence of subducted MORBdominated dehydrated slabs both can reduce the temperature of melting in the mantle. The presence of subducted continental crust material, which may serve an additional radiogenic heater, can synergistically trigger the generation of hydrous-carbonated plumes in the MTZ (Kawai et al., 2013; Safonova et al., 2015). Those hydrous-carbonated plumes can induce mantle upwelling, melting of the metasomatized mantle and formation of intra-plate magmatic complexes (Figs. 5 and 6). On the surface, the peaks of plume-related magmatism can be constrained through identification of bi-modal igneous series and OIBtype mafic rocks in the intra-continental areas of central and eastern Asia and investigation of their age and composition. Thus, the new holistic model should link (1) Ocean Plate Stratigraphy, its subduction and accretion to Pacific-type convergent margins; (2) accreting and eroding convergent margins and the processes of tectonic and subduction erosion; (3) mantle metasomatism; (4) generation of hydrous-carbonated plumes in the MTZ under the influence of water, $\mathrm{CO}_{2}$ and subducted granitic materials and oceanic slabs, and (5) intraplate magmatism in Central and East Asia (Fig. 5). Such a novel model would account the whole spectra of data from different fields of Earth Sciences and link the geological objectives and processes on the Earth's surface, which are accessible to our study, and those in the deep mantle, which are much less accessible. Finally, the model would contribute to our knowledge about the global material circulation between the crust and the mantle, deep mantle material cycles and global geodynamics.

\section{Summary}

The parameters of ancient oceans, size and age, the periods of continuous subduction and the peaks of juvenile crustal growth can be evaluated by studying OPS rocks at key accretionary complexes of central and eastern Asia. This huge region encompasses oceanic, active margin and plume-related rock formed during four major periods: late Neoproterozoic-early Paleozoic, middle Paleozoic-early Carboniferous, late Carboniferous-Permian, Triassic-Paleogene. Of special importance is to define the type of convergent margin, accreting or eroding, in ancient Pacific-type orogenic belts by evaluating the distance between coeval supra-subduction igneous rocks (arc) and accretionary units (fore-arc). The subduction of oceanic crust and tectonic and the subduction erosion at convergent margins are responsible for the delivery of volatiles, granitoids, serpentinite and basalt to the deep mantle and, finally, for intra-plate plume-related magmatism. It is necessary to outline the main periods of tectonic and subduction erosion at the active margins of the late Neoproterozoic to Cenozoic paleo-oceans which records have been preserved in accre- tionary complexes of central and eastern Asia and consequently to recognize the major stages of the supply of volatiles and oceanic and continental crust materials to the deep mantle. The holistic model of the evolution of oceans, convergent margins and "shallow-rooted" or "hydrous-carbonate" plume magmatism can be developed by the correlation of the periods of eroding convergent margins, mantle metasomatism and intra-plate continental magmatism.

\section{Acknowledgements}

This work evolved from UNESCO-IUGS IGCP\#592 project "Continental construction in Central Asia" (2011-2016) and is currently supported by the Ministry of Education and Science of the Russian Federation, grant \# 14.Y26.31.0018. Additional support came from the Russian Foundation for Basic Research (grant \# 16-05-00313) and Scientific Projects of IGM SB RAS no. 0330-2016-0003 and 03302016-0018. The comments from anonymous reviewers and handling editors of Episodes are much appreciated.

\section{References}

Alexeiev, D.V., Kroner, A., Hegner, E., Rojas-Agramonte, Y., Biske, Yu.S., Wong, J., Geng, H., Ivleva, E.A., Mühlberg, M., Mikolaichuk, A.V., and Liu, D.Y., 2016, Middle to Late Ordovician arc system in the Kyrgyz Middle Tianshan: from arc-continent collision to subsequent evolution of a Palaeozoic continental margin. Gondwana Research, v. 39, pp. 261-291.

Barrie, T.C., 1993, Petrochemistry of shoshonitic rocks associated with porphyry copper-gold deposits of central Quesnellia, British Columbia. Canada Journal of Geochemical Exploration, v. 48, pp. 225-258.

Buslov, M.M., Saphonova, I.Yu, Watanabe, T., Obut, O.T., Fujiwara, Y., Iwata, K., Semakov, N.N., Sugai, Y., Smirnova, L.V., Kazansky, A.Yu., and Itaya, T., 2001, Evolution of the Paleo-Asian Ocean (Altai-Sayan, Central Asia) and collision of possible Gondwana-derived terranes with the southern marginal part of the Siberian continent. Geosciences Journal, v. 5, pp. 203-224.

Cleven, N.R., Lin, S., and Xiao, W., 2015, The Hongliuhe fold-and-thrust belt: evidence of terminal collision and suture-reactivation after the Early Permian in the Beishan orogenic collage, Northwest China. Gondwana Research, v. 27, pp. 796-810.

Déruelle, B., 1978, Calc-alkaline and shoshonitic lavas from five Andean volcanoes (between latitudes $21^{\circ} 45^{\prime}$ and $24^{\circ} 30^{\prime} \mathrm{S}$ ) and the distribution of the Plio-Quaternary volcanism of the south-central and southern Andes. Journal of Volcanology and Geothermal Research, v. 3, pp. 281-298.

Fujisaki, W., Isozaki, Y., Maki, K., Sakata, S., Hirata, T., and Maruyama, S., 2014, Age spectra of detrital zircon of the Jurassic clastic rocks of the Mino-Tanba AC belt in SW Japan: constraints to the provenance of the mid-Mesozoic trench in East Asia. Journal of Asian Earth Sciences, v. 88, pp. 62-73.

Hilde, T.W.C., 1983, Sediment subduction versus accretion around the Pacific. Tectonophysics, v. 99, pp. 381-397.

Huang, J., and Zhao, D., 2006, High-resolution mantle tomography of China and surrounding regions. Journal of Geophysical Research, v. 111. doi: 10.1029/2005JB004066.

Ichikawa, H., Kawai, K., Yamamoto, S., and Kameyama, M., 2013, Supply rate of continental materials to the deep mantle through subduction channels. Tectonophysics, v. 592, pp. 46-52.

Isozaki, Y., 1997, Contrasting two types of orogen in Permo-Triassic Japan: accretionary versus collisional. Island Arc, v. 6, pp. 2-24. 
Isozaki, Y., Maruyama, Sh., and Fukuoka, F., 1990, Accreted oceanic materials in Japan. Tectonophysics, v. 181, pp. 179-205.

Johnston, F.K.B., Turchyn, A.V., and Edmonds, M., 2011, Decarbonation efficiency in subduction zones: implications for warm Cretaceous climates. Earth and Planetary Science Letters, v. 303, pp. 143-152.

Kawai, K., Yamamoto, S., Tsuchiya, T., and Maruyama, S., 2013, The second continent: existence of granitic continental materials around the bottom of the mantle transition zone. Geoscience Frontiers, v. 4, pp. 1-6.

Kemkin, I.V., Khanchuk, A.I., and Kemkina, R.A., 2016, Accretionary prisms of the Sikhote-Alin Orogenic Belt: composition, structure and significance for reconstruction of the geodynamic evolution of the eastern Asian margin. Journal of Geodynamics, v. 102, pp. 202-230.

Kolesnichenko, M.V., Zedgenizov, D.A., Litasov, K.D., Safonova, I.Yu., and Ragozin, A.L., 2017, Heterogeneous distribution of water in the mantle beneath the central Siberian Craton: implications from the Udachnaya Kimberlite Pipe. Gondwana Research, v. 47, pp. 249-266.

Komiya, T., Maruyama, S., Masuda, T., Nohda, S., Hayashi, M., and Okamoto, K., 1999, Plate tectonics at 3.8-3.7 Ga: field evidence from the Isua Accretionary Complex, southern West Greenland. The Journal of Geology, v. 107, pp. 515-554.

Kuramoto, S., Taira, A., Bangs, N.L., Shipley, T.H., and Moore, G.F., 2000, Seismogenic zone in the Nankai accretionary wedge general summary of Japan-U.S. collaborative 3-D seismic investigation. Journal of Geography, v. 109, pp. 531-539.

Kusky, T., Windley, B., Safonova, I., Wakita, K., Wakabayashi, J., Polat, A., and Santosh, M., 2013, Recognition of Ocean Plate Stratigraphy in accretionary orogens through Earth history: a record of 3.8 billion years of sea floor spreading, subduction and accretion. Gondwana Research, v. 24, pp. 501-547.

Kuzmin, M.I., Yarmolyuk, V.V., and Kravchinskiy, V.A., 2010, Phanerozoic hot spot traces and paleogeographic reconstructions of the Siberian continent based on interaction with the African large low shear velocity province. Earth Science Reviews, v. 102, pp. 29-59.

Li, Z., and Zhong, S., 2009, Supercontinent-superplume coupling, true polar wander and plume mobility: plate dominance in whole-mantle tectonics. Physics of the Earth and Planetary Interiors, v. 176, pp. 143-156.

Litasov, K.D., Foley, S.F., and Litasov, Yu.D., 2000, Magmatic modification and metasomatism of the subcontinental mantle beneath the Vitim volcanic field (East Siberia): evidence from trace element data on pyroxenite and peridotite xenoliths from Miocene picrobasalt. Lithos, v. 54, pp. 83-114.

Maruyama, S., Santosh, M., and Zhao, D., 2007, Superplume, supercontinent, and post-perovskite: mantle dynamics and anti-plate tectonics on the core-mantle boundary. Gondwana Research, v. 11, pp. 7-37.

Maruyama, S., Hasegawa, A., Santosh, M., Kogiso, T., Omori, S., Nakamura, H., Kawai, K., and Zhao, D., 2009, The dynamics of big mantle wedge, magma factory and metamorphic-metasomatic factory in subduction zones. Gondwana Research, v. 16, pp. 141-430.

Maruyama, S., Kawai, T., and Windley, B.F., 2010, Ocean Plate Stratigraphy and its imbrication in an accretionary orogen: the Mona complex, Anglesey-Lleyn, Wales, UK. In: Kusky, T.M., Zhai, M., and Xiao, W. (Eds.), The Evolving Continents: Understanding Processes of Continental Growth. Geological Society of London, Special Publications, v. 338, pp. 55-75.

Maruyama, S., Sawaki, Y., Ebisuzaki, T., Ikoma, M., Omori, S., and Komabayashi, T., 2014, Initiation of leaking Earth: an ultimate trigger of the Cambrian explosion. Gondwana Research, v. 25, pp. 910-944.

Maruyama, S., 1994, Plume tectonics. Journal of the Geological Society of Japan, v. 100, p. 24-49.

Metcalfe, I., 2011, Tectonic framework and Phanerozoic evolution of Sundaland. Gondwana Research, v. 19, pp. 3-21.

Morris, E.M., and Pasteris, J.D., 1987, Mantle metasomatism and alkaline magmatism. Geological Society of America, Special Paper, v. 215, 383 p.

Nance, R.D., and Murphy, J.B., 2013, Origins of the supercontinent cycle. Geoscience Frontiers, v. 4, pp. 439-448.
Pearce, J.A., Van Der Laan, S.R., Arculus, R.J., Murton, B.J., Ishii, T., Peate, J.A., and Parkinson, I.J., 1992, Boninite and Harzburgite from Leg 125 (Bonin-Mariana Forearc): a case study of magma genesis during the initial stages of subduction. In: Fryer, P., Pearce, J.A., and Stokking, I.J. (Eds.), Proceedings of the Ocean Drilling Program. College Station, pp. 623-659.

Reichow, M.K., Pringle, M.S., Al'Mukhamedov, A.I., Allen, M.B., Andreichev, V.L., Buslov, M.M., Davies, C.E., Fedoseev, G.S., Fitton, J.G., Inger, S., Medvedev, A.Ya., Mitchell, C., Puchkov, V.N., Safonova, I.Yu., Scott, R.A., and Sauders, A.D., 2009, The timing and extent of the eruption of the Siberian traps large igneous province: implication for the end-Permian environmental crisis. Earth and Planetary Science Letters, v. 277, pp. 9-20.

Safonova, I., 2014, The Russian-Kazakh orogen: an overview and main debatable issues. Geoscience Frontiers, v. 5, pp. 537-552.

Safonova, I., 2017, Juvenile versus recycled crust in the Central Asian Orogenic Belt: implications from Ocean Plate Stratigraphy, blueschist belts and intra-oceanic arcs. Gondwana Research, v. 47, pp. 6-27.

Safonova, I., and Maruyama, S., 2014, Asia: a frontier for a future supercontinent Amasia. International Geology Review, v. 59, pp. 1051-1071.

Safonova, I., and Santosh, M., 2014, Accretionary complexes in the AsiaPacific region: tracing archives of Ocean Plate Stratigraphy and tracking mantle plumes. Gondwana Research, v. 25, pp. 126-158.

Safonova, I., Seltmann, R., Kröner, A., Gladkochub, D., Schulmann, K., Xiao, W., Kim, T., Komiya, T., and Sun, M., 2011, A new concept of continental construction in the Central Asian Orogenic Belt (compared to actualistic examples from the Western Pacific). Episodes, v. 34, pp. 186-194.

Safonova, I., Seltmann, R., Sun, M., Kröner, A., Kislov, E., Kovach, V., and Collins, A., 2013, Continental construction in Central Asia (IGCP592): scientific results and meetings in 2012. Episodes, v. 36, pp. 227-234.

Safonova, I., Maruyama, S., and Litasov, K., 2015, Generation of hydrouscarbonate plumes in the mantle transition zone linked to tectonic erosion and subduction. Tectonophysics, v. 662, pp. 454-471.

Safonova, I., Biske, G., Romer, R.L., Seltmann, R., Simonov, V., and Maruyama, S., 2016c, Middle Paleozoic mafic magmatism and Ocean Plate Stratigraphy of the South Tianshan, Kyrgyzstan. Gondwana Research, v. 30, pp. 236-256.

Safonova, I., Maruyama, S., Kojima, S., Komiya, T., Krivonogov, S., and Koshida, K., 2016b, Recognizing OIB and MORB in accretionary complexes: a new approach based on Ocean Plate Stratigraphy, petrology, and geochemistry. Gondwana Research, v. 33, pp. 92-114.

Safonova, I., Seltmann, R., Sun, M., Xiao, W., Dong Y., Eyuboglu Y., Pushkarev E., and Kruk N., 2016a, Juvenile crust, mantle magmatism and metallogeny of the Central Asian Orogenic Belt. Episodes, v. 39, pp. 59-69.

Santosh, M., Maruyama, S., and Yamamoto, S., 2009, The making and breaking of supercontinents: some speculations based on superplumes, super downwelling and the role of tectosphere. Gondwana Research, v. 15 , pp. 324-341.

Scholl, D.W., and von Huene, R., 2007, Crustal recycling at modern subduction zones applied to the past - issues of growth and preservation of continental basement crust, mantle geochemistry and supercontinent reconstruction. In: Hatcher, R.D., Jr., Carlson, M.P., McBride, J.H., and Martinez Catalan, J.R. (Eds.), 4-D Framework of Continental Crust. Geological Society of America, Memoir, v. 200, pp. 9-32.

Scotese, C.R., 2004, A continental drift flipbook. Journal of Geology, v. 11, pp. 729-741.

Senshu, H., Maruyama, S., Rino, S., and Santosh, M., 2009, Role of tonalite-trodhjemite granite (TTG) crust subduction on the mechanism supercontinent breakup. Gondwana Research, v. 15, pp. 433-442.

Simonov, V.A., Mikolaichuk, A.V., Safonova, I.Yu., Kotlyarov, A.V., and Kovyazin, S.V., 2015, Late Paleozoic-Cenozoic intra-plate continental basaltic magmatism of the Tienshan-Junggar region in the SW Central Asian Orogenic Belt. Gondwana Research, v. 27, pp. 1646-1666. 
Stampfli, G.M., and Borel, G.D., 2002, A plate tectonic model for the Paleozoic and Mesozoic constrained by dynamics plate boundaries and restored synthetic oceanic isochrones. Earth and Planetary Science Letters, v. 196, pp. 17-33.

Stern, R., 2010, The anatomy and ontogeny of modern intra-oceanic arc systems. In: Kusky, T.M., Zhai, M., and Xiao, W. (Eds.), The Evolving Continents: Understanding Processes of Continental Growth. Geological Society of London, Special Publications, v. 338, pp. 7-34.

Strasser, M., Moore, G.F., Kimura, G., Kitamura, Y., Kopf, A.J., Lallemant, S., Park, J.-O., Screaton, E.J., Su, X., Underwood, M.B., and Zhao, X., 2009, Origin and evolution of a splay fault in the Nankai accretionary wedge. Nature Geoscience, v. 2, pp. 648-652.

Sun M., Yuan C., Xiao W., Long X., Xia X, Zhao G., Lin S., Wu F., and Kröner A., 2008, Zircon U-Pb and Hf isotopic study of gneissic rocks from the Chinese Altai: progressive accretionary history in the early to middle Palaeozoic. Chemical Geology, v. 247, pp. 352-383.

Taylor, R.N., Nesbitt, R.W., Vidal, P., Harmon, R.S., Auvray, B., and Croudace, I.W., 1994, Mineralogy, chemistry, and genesis of the Boninite Series Volcanics, Chichijima, Bonin Islands, Japan. Journal of Petrology, v. 35, pp. 577-617.

von Huene, R., Ranero, C., and Vannucchi, P., 2004, Generic model of subduction erosion. Geology, v. 32, pp. 913-916.

Wakita, K., and Metcalf, I., 2005, Ocean Plate Stratigraphy in East and Southeast Asia. Journal of Asian Earth Sciences, v. 24, pp. 679-702.

Wilson, M., 1989, Igneous Petrogenesis. Springer, Dordrecht, 466 p.

Windley, B.F., Alexeiev, D., Xiao, W., Kröner, A., and Badarch, G., 2007, Tectonic models for accretion of the Central Asian Orogenic Belt. Journal of the Geological Society, v. 164, pp. 31-47.

Xiao, W., Zhang, Z., and Safonova, I., 2013, International field trip and workshop "Beishan Orogen in NW China: accretionary tectonics, magmatism, eclogite and granulite complexes". Episodes, v. 36, pp. 295-297.

Yamamoto, S., Senshu, H., Rino, S., Omori, S., and Maruyama, S., 2009, Granite subduction: arc subduction, tectonic erosion and sediment subduction. Gondwana Research, v. 15, pp. 443-453.

Yang, G., Li., Xiao, W., and Tong, L., 2015, OIB-type rocks within West Junggar ophiolitic mélanges: evidence for the accretion of seamounts. Earth-Science Reviews, v. 150, pp. 477-496.

Yarmolyuk, V.V., Kuzmin, M.I., and Ernst, R.E., 2014, Intraplate geodynamics and magmatism in the evolution of the Central Asian Orogenic Belt. Journal of Asian Earth Sciences, v. 93, pp. 158-179.
Zhao, D., Maruyama, S., and Omori, S., 2007, Mantle dynamics of western Pacific to East Asia: new insight from seismic tomography and mineral physics. Gondwana Research, v. 11, pp. 120-131.

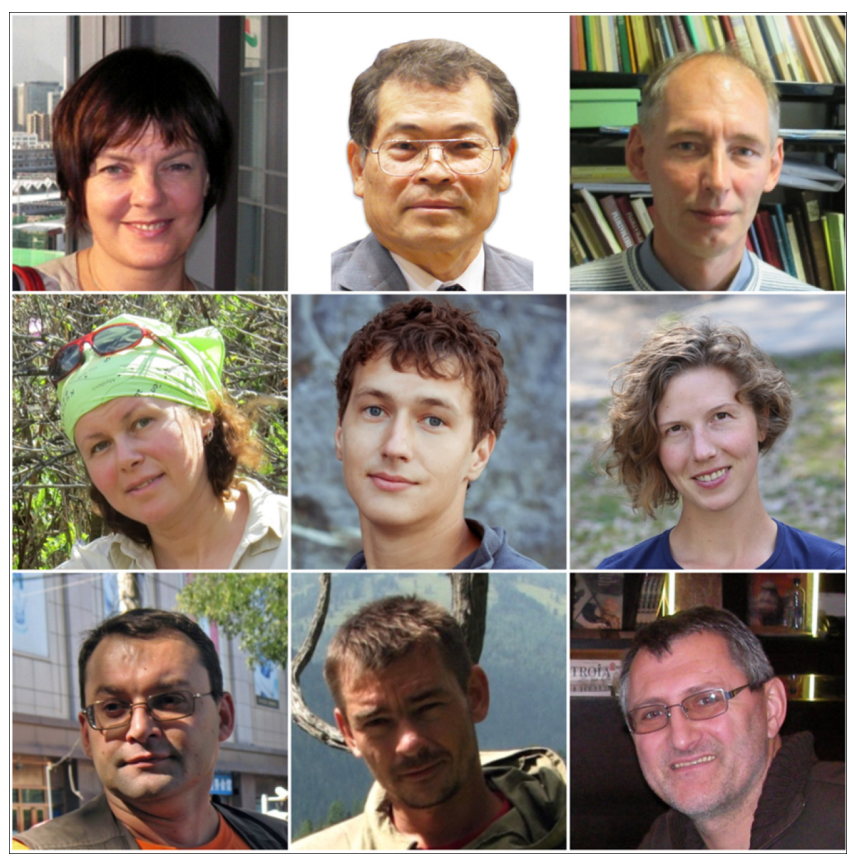

The authors (from left top to right bottom) are members of the Laboratory of Evolution of Paleo-Oceans and Mantle Magmatism (LEPOM; http:// lepom.nsu.ru/), which was established in Novosibirsk State University under Project \# 14.Y26.31.0018 "A multidisciplinary study of Pacific-type orogenic belts and development of a holistic model linking evolution of oceans, their active margins and mantle magmatism". Inna Safonova is LEPOM Chief. Shigenori Maruyama is Scientific Leader of the Project. Dr. Nikolai Kruk is a group leader of the Porject. All authors are experts in the geology, tectonics, geochronology, geochemistry and petrology of Pacific-type orogenic belts, paleo-oceans and intra-plate igneous complexes. 